\title{
Inter-Basin Groundwater Transfer and Multiple Approach Recharge Estimation of the Upper Awash Aquifer System
}

\author{
Behailu Berehanu', Tilahun Azagegn'2, Tenalem Ayenew ${ }^{2}$, Marco Masetti2 \\ ${ }^{1}$ School of Erath Sciences and Engineering, Addis Ababa Science and Technology University, Addis Ababa, Ethiopia \\ ${ }^{2}$ Department of Earth Sciences, Addis Ababa University, Addis Ababa, Ethiopia \\ Email: behailu.berehanu@gmail.com
}

How to cite this paper: Berehanu, B., Azagegn, T., Ayenew, T. and Masetti, M. (2017) Inter-Basin Groundwater Transfer and Multiple Approach Recharge Estimation of the Upper Awash Aquifer System. Journal of Geoscience and Environment Protection, 5, 76-98.

https://doi.org/10.4236/gep.2017.53007

Received: December 21, 2016

Accepted: February 17, 2017

Published: February 21, 2017

Copyright $\odot 2017$ by authors and Scientific Research Publishing Inc. This work is licensed under the Creative Commons Attribution International License (CC BY 4.0).

http://creativecommons.org/licenses/by/4.0/

\begin{abstract}
Multiple approaches have been used to estimate groundwater recharge in the Upper Awash river basin. The amount of recharge reaching the Upper Awash aquifer system from the Blue Nile sub-basins is also estimated. Water Balance, Chloride Mass Balance and HYDRUS 1D infiltration model are used to estimate recharge. A total of 29 sites were selected for the HYDRUS 1D multiple "at point" recharge simulations. Base Flow Separation (BFS) methods, using both River Analysis Package software Version 3.0.3 and Excel-based Time Plot program are also used as a proxy for recharge. Besides, overlay analysis in Processing MODFLOW, ArcGIS, and SURFER environments has been done to thoroughly consider spatial heterogeneity between any two point estimates and appreciate the effect of lineament density, topography, slope and major urbanized land on pattern of spatial distribution of recharge. Because of differences inherent in the assumptions and datasets used, the various methods employed give wide range of differences in recharge estimates. Recharge estimated for the Upper Awash basin ranges from $51.5 \mathrm{~mm} /$ year to $157 \mathrm{~mm} /$ year and for the two southern left-bank sub-basins of the Middle Blue Nile basin (Mugher and Jema) ranges from $86 \mathrm{~mm} /$ year to $239 \mathrm{~mm} /$ year. Consequently, annual average volumetric recharge in the Upper Awash and annual groundwater flux from portion of the Blue Nile sub basins to the Upper Awash aquifer system are estimated to be $983 \mathrm{Mm}^{3}$ and $365 \mathrm{Mm}^{3}$ respectively. The significant flux joining the Upper Awash groundwater system from part of the Middle Blue Nile basin, which is almost $37 \%$ of the total annual recharge to the Upper Awash basin makes this part of the Middle Blue Nile basin an important recharge zone for the Upper Awash groundwater. Estimating recharge using integrated approaches was found to be useful to identify range of plausible recharge rates in the two basins. Besides, the new methodological approach of superimposing recharge governing factors on interpolation of point
\end{abstract}


recharge estimates helps to produce physical based spatial distribution of recharge.

\section{Keywords}

Upper Awash, Recharge, Inter Basin Groundwater Flow, Multiple Recharge Estimation

\section{Introduction}

Recharge is one of the most important components in hydrogeological characterization of aquifer systems and the major objectives in hydro-meteorological studies [1]. Whereas some studies focus on recharge estimates for water resource assessment [2] [3] [4], others concentrate on estimates for contaminant transport or aquifer vulnerability to contamination [5] [6] [7]. Either way, understanding and quantifying recharge to the aquifer system of the area is very important to properly characterize the aquifer system, flow characteristics and water resource management for sustainable use and benefit of the different water users.

Various techniques are available to quantify recharge [8]-[20]. However, due to many factors governing location and timing of recharge (climate, geomorphology, litho-structural setting, and water table), there are a number of short comings inherent to each recharge estimation techniques. Many of the problems encountered with each recharge estimation methods have been addressed by many authors [21]-[27]. Summary comparisons of the various methods are offered by [13] [21] [24] [25]. Uncertainties in each approach to estimating recharge underscore the need for application of multiple techniques to increase reliability of recharge estimates. A common recommendation is that recharge should be estimated by the use of multiple methods and the results be compared [28] [29] [30].

Surrounding the city of Addis Ababa, Upper Awash groundwater basin supports about $60 \%$ of domestic water supply of the city and it is becoming major source for domestic and industrial uses in the region. Almost all the towns and rural villages surrounding Addis Ababa within $100 \mathrm{~km}$ radius use this groundwater for their domestic water supply source. However, despite such keen interest in groundwater use, reliable estimate from detailed evaluations of recharge has not been made. As a result, fundamental aspects of groundwater recharge such as its source, timing, magnitude and distribution have not been well defined. Previous recharge investigations in the study area have tended to rely on the use of a single recharge estimation technique and lacked corroborating evidence to substantiate predictions of recharge using multiple approaches.

In most cases, water table is a subdued replica of the topography of the land where groundwater divide matches with surface water divides. However, under certain circumstances, groundwater flows across surface water divides. The flow may continue through adjacent basins and to any intervening ranges, as long as 
the permeable rocks are continuous and sub-surface geometric architecture is favorable for groundwater movement [31]. Previous hydrogeological, hydrogeochemical and environmental isotope studies have treated the Blue Nile and Awash basins as separate hydrogeological systems, as if the surface water divide coincides with the groundwater divide [32]-[39]. However, recent works [40]-[46] showed that the aquifer system of the Upper Awash basin has hydraulic connection with the aquifer system of the two adjacent southern left-bank sub-basins of the Blue Nile (Abbay) river basin (Mugher and Jema). Integrated study revealed that the interplay between the regional fault systems found to control the inter-basin transfer of the groundwater from the Middle part of the Blue Nile to the aquifer systems of the Upper Awash basin [45]. In the same work, recharge boundary for the aquifer systems of the Upper Awash groundwater basin has also been delineated. Nonetheless, though the hydraulic connection between aquifer systems of the Middle Blue Nile and the Upper Awash basins has been addressed and recharge boundary have been well defined, recharge contribution from the two sub-basins of Blue Nile to the aquifer systems of the Upper Awash groundwater basin has not been quantified in detail.

Hence, in this work, the results of multiple recharge estimations in the Upper Awash and contribution of recharge to the aquifer systems of the Upper Awash groundwater basin from the two southern left-bank sub-basins of the Middle Blue Nile basin are separately presented in order to appreciate recharge contribution from each basin (Figure 1). Recharge estimation has been made using Water Balance Method (WBM), Chloride Mass Balance (CMB) [47], and Base Flow Separation (BFS) approaches together with integration of results therein. Such techniques are capable of producing quantitative information using commonly available data (i.e., precipitation, evapotranspiration, land use/land cover). However, to overcome the criticisms inherent in comparable studies, one dimensional recharge estimation technique HYDRUS 1D [48] [49] [50] [51] is also used to support the recharge results in this study, thereby providing a valuable insight into the nature of spatial variability of recharge in this environment.

This study also suggests an approach accounting different factors controlling recharge, such as topography, slope, major urban settlements, and lineament density under Processing MODFLOW (PMWIN), ArcGIS and SURFER environments to enhance linear geo-statistical interpolations of point recharge estimations and produce physical based pattern of spatial distribution of recharge. Though the approach is described on multiple "at point" simulation of recharge using HYDRUS 1D, it is also possible to apply the same procedures to fairly distributed point recharge estimations from any point recharge estimation techniques.

\section{Study Area}

The study area is located in central Ethiopia and covers the Upper Awash River basin with a total recharging area of $6735 \mathrm{~km}^{2}$ and portions of the two southern flank of the Middle Blue Nile River basin (Mugher and Jema) with an area of 
$1770 \mathrm{~km}^{2}$ and $304 \mathrm{~km}^{2}$ respectively. The entire area is bounded within $8^{\circ} 23^{\prime}$ $30.9925^{\prime \prime} \mathrm{N}$ to $9^{\circ} 23^{\prime} 11.3507^{\prime \prime} \mathrm{N}$ latitude and $37^{\circ} 59^{\prime} 11.3953^{\prime \prime} \mathrm{E}$ to $39^{\circ} 06^{\prime} 2.1014 " \mathrm{E}$ longitude and covers a total surface area of $8809 \mathrm{~km}^{2}$ (Figure 1).

Due to large topographic variations in the area $(1650 \mathrm{~m}-3650 \mathrm{~m}$, a.s.l.), there is great variability in climate. It is warm and humid in the lowland sand cold and dry in the highlands. The climatic characteristics are determined largely by movements of the currents running throughout the country, in particular by westerly winds from the Atlantic and eastern and southern currents coming from the Indian Ocean, which are the "sources" of rainfall occurring in the area. Rainfall is concentrated almost entirely in two periods; the first starts in February and ends in late April, when they arrive in the area of air currents wet from the South-East making the climate unstable causing the rainy season short (Belg rain). The second period, characterized by heavier rainfall (Kiremt rain), is

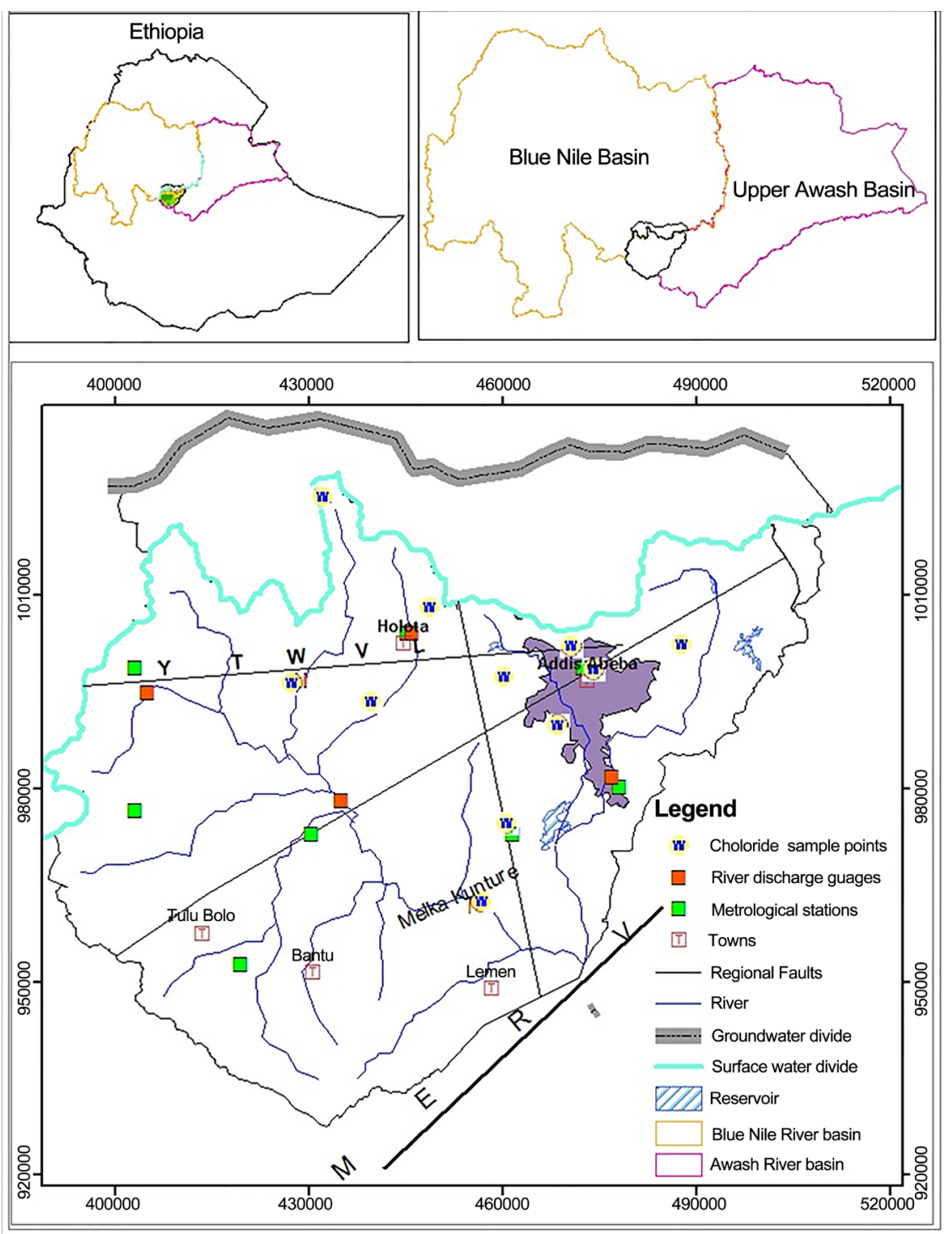

Figure 1. Location map of Upper Awash and south eastern flank of the Middle Blue Nile basins in central Ethiopia. 
between June and September, where the humid winds from the Indian and the Atlantic oceans converge in the Ethiopian Highlands [52]. Annual average precipitation determined from Arithmetic mean, Theissen and Isohyetal methods is $1077 \mathrm{~mm}$. On average, annual potential evapotranspiration estimated using Penman combination and Thornth weight methods is $871 \mathrm{~mm}$. The mean annual minimum and maximum temperature is 5 and $25.1^{\circ} \mathrm{C}$ respectively [53] [45].

\section{Methods Employed}

Unlike the accurate water table fluctuations record used for recharge estimation [28], each method employed in this study are based on surface and unsaturated zone data which provides estimates of potential recharge, which is percolation below the root zone that should reach the water table in the future [54] or net recharge, which is recharge minus groundwater evapotranspiration or leakage to a deeper aquifer [55]. The methods utilized in this study are described in brief below.

\subsection{Water Balance Method (WBM)}

As it is attractive, because it can be applied almost anywhere precipitation data are available, there is a drawback of the water balance method due to short comings inherent to the techniques used [29]. Recharge in the water balance equation is estimated as the residual term in an equation where the other budget terms usually are estimated with considerable error. Nonetheless, despite its shortcomings, the water-balance method is a powerful tool to understand the main features of recharge processes, if short time steps are used and the spatial variability of components is taken into account. The basic concept of water balance method within a given period of time is: Input to the system-Outflow from the system $=$ change in storage of the system.

In the study area, the inflow components include recharge from precipitation and groundwater inflow from inter-basin groundwater flow. The outflow components include Actual Evapotranspiration (AET), runoff, and inter-basin groundwater outflow and groundwater withdrawal by pumping. Considering the above inflow and outflow components, the general groundwater balance equation to estimate recharge in the area under consideration for a given time period with the same unit is given as:

$$
R=P+G_{i}+E T-R_{o}-G_{o}-W
$$

where: $R$ is recharge, $P$ is mean precipitation, $E T$ is mean actual evapotranspiration, $R_{o}$ is mean runoff, $G_{i}$ is groundwater inflow, $G_{o}$ is groundwater outflow and $\mathrm{W}$ is withdrawal of groundwater from the aquifer system.

Groundwater is being used by sparsely distributed settlements, villages and small towns. Therefore, withdrawal of groundwater for consumptive use by pumping is negligible for Mugher, and Jema sub-basins of the Blue Nile basin. On the other hand, significant amount of groundwater is being pumped from the Upper Awash basin mainly for domestic and industrial purposes in a number of cities. Annual extraction of water from the groundwater source has been 
estimated based on daily groundwater abstraction information from Addis Ababa Water Supply and Sewerage Authority (AAWSA).Rough estimation has been made using the following assumption for other groundwater users (dug wells fitted with hand pump discharge rate of $0.5 \mathrm{l} / \mathrm{s}$ for $8 \mathrm{hrs} / \mathrm{d}$, shallow wells fitted with hand pump discharge rate of $1 \mathrm{l} / \mathrm{s}$ for $8 \mathrm{hrs} / \mathrm{d}$, deep private wells used for households fitted with submersible pump, discharge rate of $1.5 \mathrm{l} / \mathrm{s}$ for 8 $\mathrm{hrs} / \mathrm{d}$, deep private wells used for hotels, small farms and water consuming factories, fitted with submersible pump, discharge rate of $5 \mathrm{l} / \mathrm{s}$ for $8 \mathrm{hrs} / \mathrm{d}$ ).

The above assumptions are based on communications and information from groundwater users in the area and from personal communications with professionals working for AAWSA. In total, data from more than 500 wells were used to quantify daily and annual abstraction from the aquifer in the Upper Awash groundwater basin. Annually, about $256 \mathrm{Mm}^{3}$ water is being pumped out, which is equivalent to $29 \mathrm{~mm} /$ year over the basin.

Neglecting groundwater inflow and outflow, recharge to the sub-basins has been calculated from the hydrological variables using the following relation and the results are given in Table 1.

$$
R=P-A E T-R O-W
$$

The evidence based conceptual model from geological characterization confirms that significant portion of Mugher sub-basin and some portion of Jema sub-basin (Figure 2) with an area of $1770 \mathrm{~km}^{2}$ and $304 \mathrm{~km}^{2}$ respectively contribute groundwater inflow to the Upper Awash groundwater basin [45]. Hence, recharge to the Mugher and Jema and the Upper Awash sub-basins has been calculated from hydrological variables using Equation 2 and the result is given in Table 2.

Total volumetric recharge to the Mugher and Jema groundwater sub-basins is, therefore equal to the difference between total volumetric recharge into the respective sub-basins minus volumetric recharge in the contributing areas. This groundwater outflow from the Mugher and Jema sub-basins has been calculated using the size of recharge areas of the two sub-basins contributing groundwater flux to the Upper Awash groundwater basin as a factor of the mean annual recharge in the respective sub-basins. Hence, annual recharge to the Mugher and Jema groundwater sub-basins gets smaller with the amount equal to the groundwater flux to the Upper Awash groundwater basin (Table 2).

Due to groundwater flux from the Mugher and Jema sub-basins, the water balance equation for the Upper Awash groundwater basin has a form:

Table 1. Hydrological variables and annual recharge from the WBM.

\begin{tabular}{cccccc}
\hline Sub-basin & Precipitation & Actual evaporation & Runoff & Withdrawal & R $(\mathrm{mm})$ \\
\hline Mugher & 1201 & 806 & 233 & Negligible & 162 \\
Jema & 993 & 588 & 272 & Negligible & 133 \\
Upper Awash & 1150 & 746 & 274 & 29 & 82.6 \\
\hline
\end{tabular}




$$
R=(P-E T-R O-W)+G
$$

Using the hydrologic variables estimated to the Upper Awash basin and, inflow from Mugher and Jema sub-basins, volumetric recharge to the Upper Awash groundwater basin has been calculated (Table 3 ).

\subsection{Chloride Mass Balance (CMB)}

The CMB method assumes that the flux of tracer $\left(\mathrm{Cl}^{-}\right)$input at the surface equals the flux of tracer reaching the groundwater table. The conservative nature of chloride ion made it to be chemically retained in solutions [56]. The technique

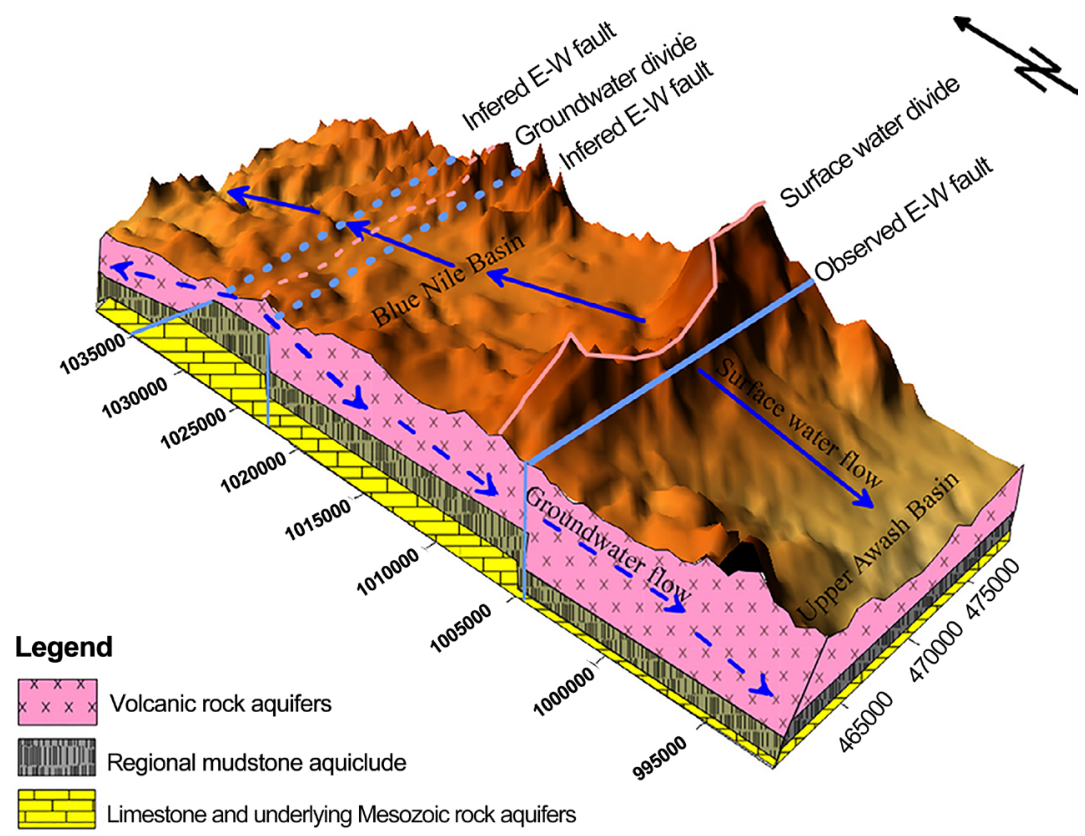

Figure 2. Simplified conceptual groundwater flow model for the Upper Awash groundwater basin [45].

Table 21. Annual inflow to the Upper Awash groundwater basin from WBM.

\begin{tabular}{cccc}
\hline Sub-basin & Recharge $(\mathrm{mm})$ & Contributing area $\left(\mathrm{km}^{2}\right)$ & $\begin{array}{c}\text { Total groundwater inflow to Upper } \\
\text { Awash basin }\left(\mathrm{Mm}^{3}\right)\end{array}$ \\
\hline Mugher & 162 & 1770 & 286.7 \\
Jema & 133 & 304 & 40.3 \\
Total & & 327 \\
\hline
\end{tabular}

Table 3. Hydrologic variables and annual recharge to the Upper Awash from WBM.

\begin{tabular}{cccccccc}
\hline Sub-basin & P & AET & Ro & W & $\begin{array}{c}\text { R } \\
(\mathrm{mm})\end{array}$ & $\begin{array}{c}\text { Area } \\
\left(\mathrm{km}^{2}\right)\end{array}$ & $\begin{array}{c}\text { Total } \\
\left(\mathrm{Mm}^{3}\right)\end{array}$ \\
\hline Upper Awash basin & 1112 & 746 & 274 & 9.4 & 82.6 & 6760 & 558 \\
Groundwater outflow from Mugher and Jema \\
sub-basins equal to inflow to the Upper Awash basin
\end{tabular}


considers chloride as an inert element, and compared with other inorganic ions, it is not added or removed by water-rock interaction. The element is considered as an inert in the hydrological cycle having its source from the atmosphere. It has the advantage over tracers involving water molecules in a sense that atmospheric inputs are conserved during recharge processes allowing a mass balance approach to be used. It should be noted that there are no evaporates or large scale thermal activities that adds chloride to the groundwater system. As described by [57], the basic Equation (4) applicable for the estimation of recharge using $\mathrm{CMB}$ is:

$$
R=(P C l p) / C l g
$$

where: $R$ is the annual recharge $(\mathrm{mm}), P$ is the mean annual precipitation $(\mathrm{mm})$, $C l p$ is chloride concentrations of the precipitation $(\mathrm{mg} / \mathrm{l})$ and $C l g$ is chloride concentrations of the groundwater $(\mathrm{mg} / \mathrm{l})$. Since chloride concentration becomes higher as the groundwater vertically percolates and crosses clay layers and fault gauges due to retardation and concentration of chloride ions, values from deep wells were excluded. Only average concentrations of chloride in groundwater from shallow wells are considered. Chloride concentrations of the precipitation samples collected from the three sub-basins at the same time were used as representative of chloride concentrations of the precipitations of the sub-basins (Figure 1). The estimated recharge values using the CMB method vary with the chloride content in the groundwater and precipitation. Taking the mean values of chloride content in the groundwater into consideration, average annual recharge values to the sub-basins were estimated (Table 4).

\subsection{Base Flow Separation (BFS)}

The most basic difference between base flow separation and the other recharge estimation methods is that, this method is designed to quantify part of the stream flow hydrograph attributed to groundwater discharge, whereas, all the other methods estimate the amount of water added to the water table. Base flow has been used as an approximation of recharge for the Upper Awash and part of the Blue Nile sub basins (Mugher and Jema) with the acknowledgement that it is probably less than the amount recharging the groundwater system [58]. Daily river discharge records from ten stations were used for the analysis. The separation of surface runoff and base flow has been made using a computer code RAP (version 3.0.3) and Excel-based Time Plot program. The weighted mean base flows, representative of the sub-basins, were obtained from the base flows of the

Table 42. Annual recharge from CMB method.

\begin{tabular}{|c|c|c|c|c|c|c|c|}
\hline \multirow[b]{2}{*}{ Sub-basin } & \multirow{2}{*}{$\mathrm{P}(\mathrm{mm})$} & \multicolumn{4}{|c|}{ Chloride concentration $(\mathrm{mg} / \mathrm{l})$} & \multirow{2}{*}{$\begin{array}{l}\text { Groundwater } \\
\text { data points }\end{array}$} & \multirow{2}{*}{$\begin{array}{l}\text { Recharge } \\
(\mathrm{mm})\end{array}$} \\
\hline & & $\begin{array}{c}\text { In } \\
\text { precipitation }\end{array}$ & $\begin{array}{l}\text { In groundwater } \\
\text { minimum }\end{array}$ & $\begin{array}{l}\text { In groundwater } \\
\text { Maximum }\end{array}$ & $\begin{array}{c}\text { In groundwater } \\
\text { average }\end{array}$ & & \\
\hline Mugher & 1201 & 0.88 & 2.20 & 10.60 & 7.1 & 7 & 148 \\
\hline Jema & 992 & 0.97 & 2.00 & 13.10 & 7.9 & 11 & 122 \\
\hline
\end{tabular}


gauged streams weighted with their respective catchment areas. Estimated mean annual recharge from base flow separation over the Mugher, Jema and the Upper Awash are $158 \mathrm{~mm}, 86 \mathrm{~mm}$ and $91.25 \mathrm{~mm}$, respectively.

\subsection{HYDRUS 1D Model}

HYDRUS 1D model is a finite element numerical model for that simulates the movement of water, heat, and multiple solutes in variably saturated media. When only considering groundwater flow, the program numerically solves the Richards' equation for saturated-unsaturated flow as indicated in Equation (5).

$$
\frac{\partial \theta}{\partial t}=\frac{\partial}{\partial z}\left(K+D \frac{\partial \theta}{\partial Z}\right)
$$

where $\theta$ is moisture content of the soil, $K$ is hydraulic conductivty, $D$ is soil water difussivity, $z$ is water pressure and $t$ is time. The Flow equation incorporates a sink term to account for water uptake by plant roots [49] [50] [59] [60]. The water content term is evaluated using the mass conservative method proposed by [61]. Groundwaterof the Upper Awash aquifersystem recharge has been evaluated using hydrometeorological and physical data for 18 simulation sites. Besides, the contribution coming from part of the Middle Blue Nile sub basins (Mugher and Jema), to the Upper Awash aquifer system has been evaluated separately by taking 11 simulation sites (Figure 3).

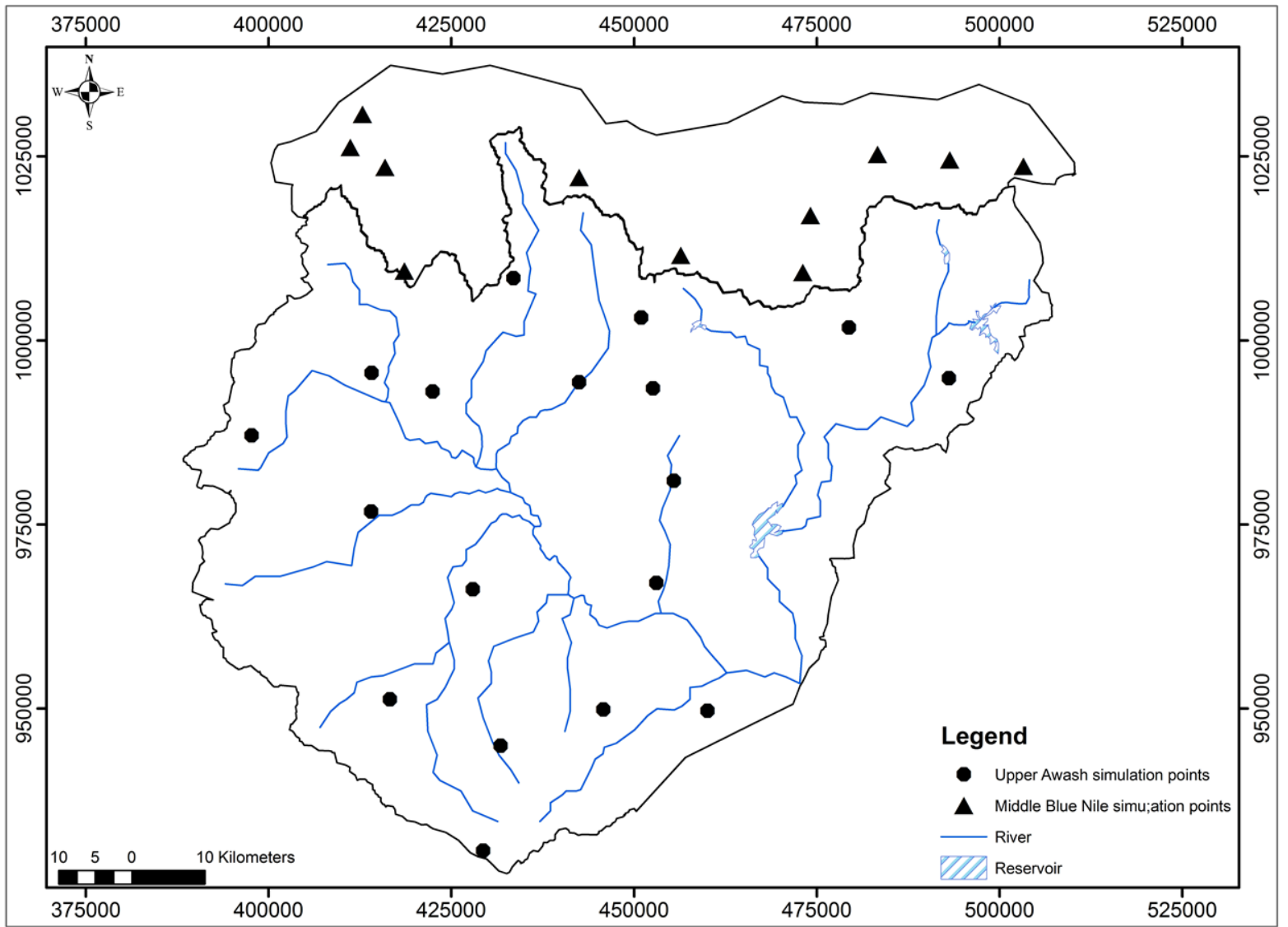

Figure 3. Simulation sits at Upper Awash and at Blue Nile (Mugher and Jema). 
Mean monthly meteorological data records (precipitation, temperature, humidity, wind speed, sunshine hour) have been used to perform the numerical simulation. Though there are many meteorological stations available in the study area, only records with complete measurements were considered for the analysis (Figure 1). Before the analysis and interpretation, all the data from National Meteorological Agency (NMA) and from the Ministry of Water, Irrigation and Electricity (MoWIE) were checked for their quality.A set of global climate layers (climate grids) with a spatial resolution of about 1 square kilometer is used from WorldClim for the purpose of validating meteorological records [62]. The WorldClim interpolated climate layers are made using sources including major climate databases compiled by the Global Historical Climatology Network (GHCN), the FAO, the WMO, and the International Center for Tropical Agriculture (CIAT), R-HYdronet).In addition to meteorological records, soil and land use/land cover maps are used from modified FAO land use/land cover and soil maps of Ethiopia [53]. Characteristics of soil (percentage of sand silt clay, specific weight and field capacity) have been extracted from soil grid project for six soil profiles, up to a depth of $200 \mathrm{~cm}$ (http://www.soilgrids.org/).

In total, 29 sites have been selected to perform numerical analysis on the basis of few requirements, in terms of combination of soil type and soil use.According to the specific climatic, soil type and soil use of the simulation sites, infiltration and evapotraspiration have been evaluated both for the Upper Awash (Table 5) and for the Mugher and Jema sub-basins (Table 6).

Table 5. Estimated annual recharge and PET for the Upper Awash.

\begin{tabular}{|c|c|c|c|c|}
\hline Code & UTME & UTMN & Recharge (mm/yr.) & PET (mm/yr.) \\
\hline B2.1 & 455451 & 980944 & 229.08 & 635.58 \\
\hline B3.1 & 433496 & 1008459 & 270.02 & 647.83 \\
\hline $\mathrm{C} 1.1$ & 460061 & 949681 & 122.00 & 743.38 \\
\hline $\mathrm{C} 2.1$ & 414046 & 976771 & 187.67 & 725.24 \\
\hline C 3.2 & 397691 & 987088 & 207.42 & 777.60 \\
\hline C6.1 & 445808 & 949849 & 128.09 & 743.44 \\
\hline $\mathrm{D} 2.1$ & 427961 & 966184 & 157.72 & 768.48 \\
\hline $\mathrm{D} 2.2$ & 493096 & 994862 & 110.28 & 771.53 \\
\hline $\mathrm{D} 2.3$ & 453061 & 967056 & 119.19 & 746.96 \\
\hline D2.4 & 416602 & 951249 & 182.71 & 728.62 \\
\hline $\mathrm{D} 2.5$ & 422451 & 993066 & 196.88 & 773.17 \\
\hline D2.6 & 414106 & 995587 & 206.21 & 768.26 \\
\hline D3.1 & 442481 & 994316 & 175.66 & 757.33 \\
\hline D5.1 & 431751 & 944951 & 192.91 & 717.19 \\
\hline E2.1 & 450979 & 1003107 & 43.98 & 957.66 \\
\hline E3.1 & 479394 & 1001746 & 42.64 & 995.29 \\
\hline F3.1 & 429347 & 930683 & 188.14 & 736.96 \\
\hline G1.1 & 452590 & 993484 & 78.52 & 973.78 \\
\hline
\end{tabular}




\section{Comparison of Methods}

The four methods used to estimate recharge to the sub-basins gave a wide range of values, Table 7. These methods produce estimates of recharge that reflect different spatial and temporal scales; have different data requirements, strengths, and limitations. In general, comparing the results may be difficult because of differences inherent in the methods.

The WBM gives a very rough estimation because: 1) it is based on sparsely distributed data from few stations to estimate representative values for very large areas, 2) since recharge is estimated as the residual term in the water balance equation, where the other budget terms (P, AET, R and groundwater withdrawal) were estimated with assumptions, possibly leads to some error.

Despite the fact that the CMB method is simple, there are a number of uncertainties associated with the method in estimating recharge. One of the uncertainties arises from using a one time record of chloride concentration in precipitation as a representative value. Another uncertainty source for the chloride mass balance approach is the sampling density of the groundwater. The biggest uncertainty is also associated with the analytical precision of the determination of chloride concentration of precipitation and groundwater. The CMB method, therefore, gives rough estimation of recharge to the sub-basins.

Table 6. Estimated annual recharge and PET for part of Blue Nile sub basins (Mugher and Jema).

\begin{tabular}{lllll}
\hline Code & UTME & UTMN & Recharge (mm/yr.) & PET (mm/yr.) \\
\hline A1.1 & 483334 & 1025290 & 263.68 & 667.52 \\
A2.1 & 493207 & 1024537 & 263.39 & 659.72 \\
B1.1 & 474134 & 1016996 & 270.95 & 553.47 \\
C3.1 & 418583 & 1009441 & 209.78 & 704.55 \\
C5.1 & 442489 & 1022149 & 181.38 & 739.42 \\
D1.1 & 456395 & 1011558 & 286.08 & 654.52 \\
D4.1 & 503282 & 1023658 & 248.35 & 676.38 \\
E1.1 & 473099 & 1009233 & 186.82 & 780.89 \\
F1.1 & 415927 & 1023526 & 228.50 & 776.63 \\
F2.1 & 411201 & 1026225 & 245.63 & 748.19 \\
F4.1 & 412871 & 1030731 & 245.03 & 761.03 \\
\hline
\end{tabular}

Table 7. Summary of annual recharge estimates from different methods.

\begin{tabular}{ccccc}
\hline \multirow{2}{*}{ Sub-basin } & \multicolumn{4}{c}{ Recharge (mm/yr.) } \\
\cline { 2 - 5 } & WBM & CMB & BFS & HYDRUS \\
\hline Mugher & 125 & 148 & 158 & 239 \\
Jema & 130 & 122 & 86 & 157 \\
Upper Awash & 131 & 135 & 91.25 & \\
\hline
\end{tabular}


When compared with the WBM and CMB, the BFS method result is supported by sufficient data from ten river gauging stations in the study area. River discharge data from gauged streams of varying catchment areas for streams flowing through different geologic units were used for the analysis of the BF component. Hence, recharge estimates from the BFS method can be taken more reliable than the values from the other two methods, as they were calculated from river discharge data representing small catchment areas, as well as nearly uniform geology and land uses/land cover features. However, recharge estimate from base flow separation methods is used as a proxy for recharge and sometimes referred to as "effective recharge" [58], "base recharge" [63], or "observable recharge" [64]. In general, base flow equals groundwater discharge, and that groundwater discharge is approximately equal to recharge. Because of the assumptions that groundwater losses from the gauged watershed caused by underflow, groundwater evapotranspiration, and exports of groundwater are minimal, it usually represents some amount less than the actual recharge. In fact the base flow approach may not account the percolation that reaches to deeper aquifers that do not have direct hydraulic link with rivers.

\section{Accounting Topography, Slope, Lineament Density, and Major Urban Areas}

There are perennial difficulties associated with recharge estimations: sparse information, the spatial extrapolation of "at-point" data, the assessment and regional hydrological consequences of localized recharge and the impacts of urban development on groundwater recharge. Though considerable progress has been made, not all these "problems" have been satisfactorily resolved [65] [66] [67]. This section of the paper addresses some of the above challenges. Particular attention is accorded to pattern of recharge space variability with respect to topography and slope; localized recharge due high lineament density; and impact of urban settlement components.

Precipitation is the principal source for replenishment of moisture in the soil water system to recharge groundwater. The amount of moisture that will eventually reach the water table is going to recharge aquifer system in sub-surface. The amount of recharge to the aquifer system depends upon the rate and duration of precipitation, topography, soil texture and moisture conditions, depth to the water table and underlying litho-structural setting [1]. Any recharge estimation technique at point locations, possibly take all or some of the recharge controlling factors into account. However, to map spatial variability of recharge using recharge estimates at point locations, interpolation of the point results is needed. Interpolation techniques such as kriging, spline, IDW are entirely controlled by recharge values from point estimations and result spatial distributions without any physically based pattern. Ideally, if fairly distributed point recharge estimates are made in any area of interest, interpolation of the point recharge estimates should follow the pattern of topographic variation. Similarly, the effect of slope, lineament density or major settlements should be clearly depicted in the 
pattern of recharge distribution. However, due to sparse data or assumptions in-built to the different interpolation techniques, spatial distribution of recharge do not follow strictly pattern of physical factors controlling recharge. This is mainly because the different techniques ignore heterogeneity between point estimates.

In order to account the effect of the controlling factors on pattern of spatial variability of recharge for the Upper Awash and its contributing part from the Middle Blue Nile sub-basins (Muger and Jema), HYDRUS 1D point results, at 18 and 11 simulation sites respectively, have been interpolated first by ordinary kriging interpolation technique (Figure 4). The two basins have been considered as independent areas and the interpolation procedure has been done separately for each basin without mixing data of the two areas. As it is observed, it is impossible to appreciate the impact of topography, slope, lineament density or urban settlements on the possible pattern of recharge distribution with such simple geo-statistical interpolation of point recharge estimates.

In order to constrain the random spatial variability of recharge by topography, which influence not only the amount, but also the distribution of recharge, the raster surface constructed by interpolation of the 18 and 11 simulation points recharge estimates for the Upper Awash and southern flank sub-basins of the

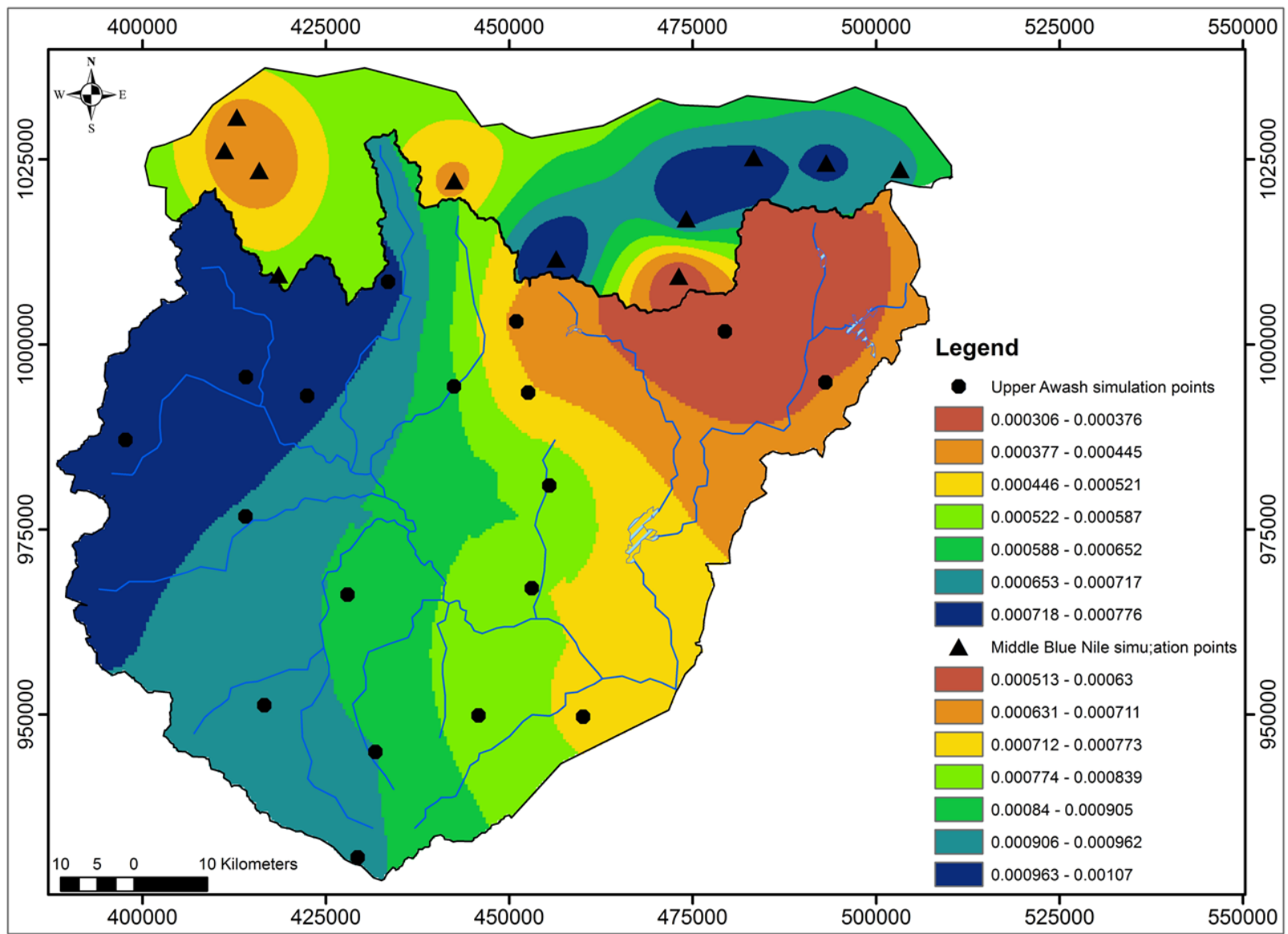

Figure 4. Interpolation of HYDRUS point estimates usingng orinary kriging for the UA and part of Blue Nile. 
Middle Blue Nile River basin respectively, were converted to $500 \mathrm{~m}$ by $500 \mathrm{~m}$ ASCII grid file in ArcGIS environment. The topographic surfaces of the same areas have also been sliced into the same grid size in Global Mapper software.

For the main reason that flow models become increasingly utilized for management decisions, and quantifying the spatial and temporal distribution of natural groundwater recharge is usually a prerequisite for effective groundwater modeling, the topographic surface have been imported in processing MODFLOW environment under topography grid. Then, using the inbuilt algorism, five topographic classes based on topographic zones have been created. Since the purpose of the procedure is to influence the pattern of recharge spatial variability, but not to significantly change the values of recharge from the point estimates, very small weighting factors have been assigned for each class.

The recharge ASCII grid is imported in PMWIN and superimposed with the topography matrix. The matrix resulted from overlaying recharge and topography is finally exported to SURFER10 (Golden software 2011) and converted to ArcGIS compatible format (GRD. surfer 6 text). From which, recharge zones constrained by topographic variation were produced for Upper Awash and part of the Middle Blue Nile basins (Figure 5).The same procedure was followed to account slope in the pattern of spatial variability of recharge (Figure 6).

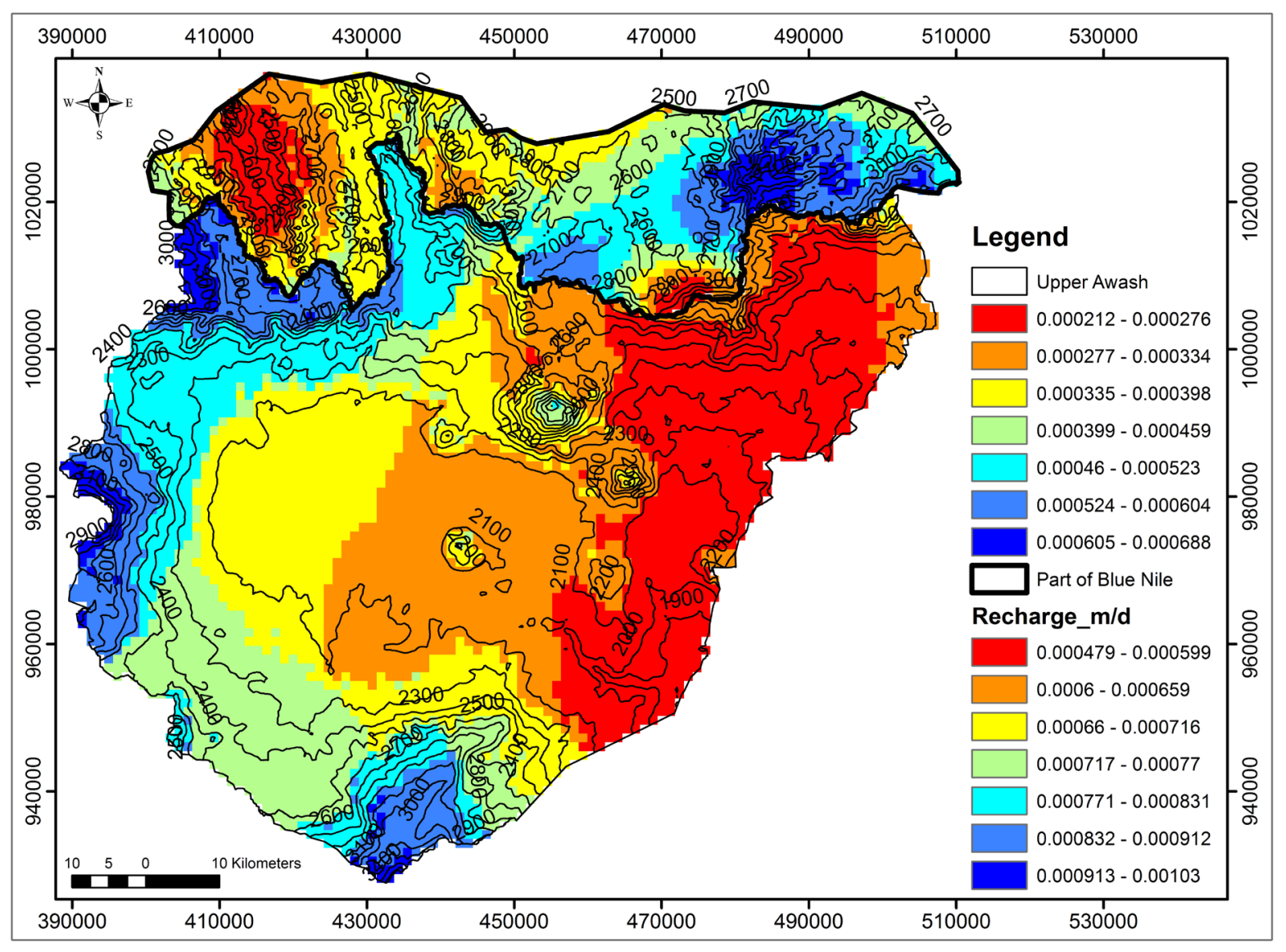

Figure 5. Recharge zones based on HYDRUS 1D model results interpolation superimposed on topography in the Upper Awash and part of Blue Nile. 


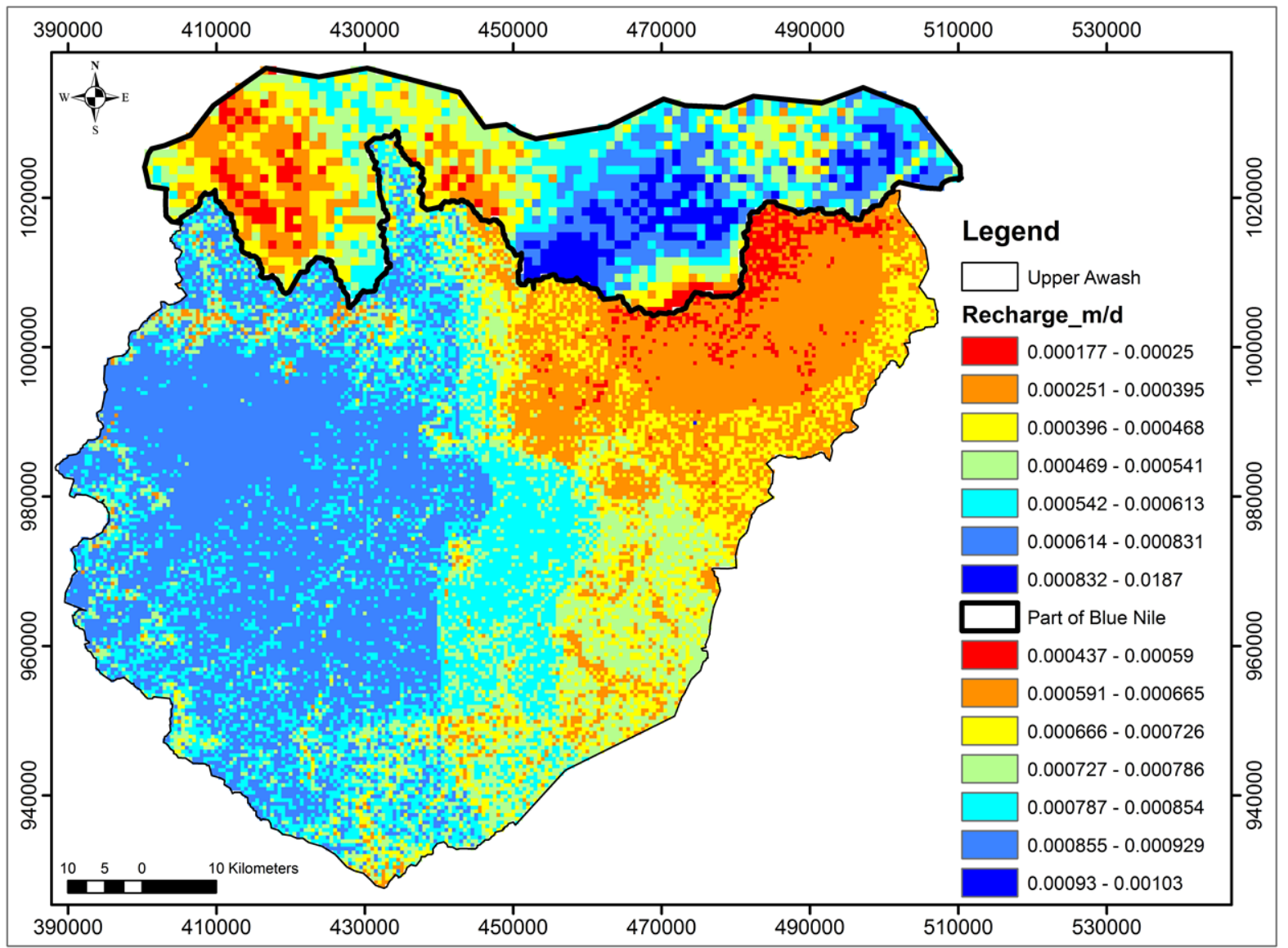

Figure 6. Recharge zones based on HYDRUS 1D model results interpolation superimposed on slope in the Upper Awash and part of Blue Nile.

The study area is located in the vicinity of Addis Ababa which lies at the intersection between the two main systems of tectonic region: the Main Ethiopian Rift (MER) with orientation NNE-SSW and the alignment Yerer Tullu Welel Volcanic Lineament (YTWVL) with EW direction (Figure 1). The acidic or silicic volcanic rocks of Intoto are confined to the area along this lineament [68]. Another important feature is the Filwuha fault having oriented NE-SW [67]. Most of the features present in the study area follow the trend of the Rift. The density of tectonic features increases toward South-East or towards the Rift Valley. Some of the basaltic lava and ash cones appear to have leaked from these features, in particular those concentrated in the main regional tectonic system, having trends NE-SW.

Hence, along with topography and slope variation in the area, these lithostructural features together with the major urban settlement, Addis Ababa city, play paramount role in shaping the pattern of spatial variability of recharge. Accordingly, similar procedures have been followed to create raster and grid surfaces of lineament density and urban settlement. The major urban settlement is only found in the Upper Awash. Figure 7 shows spatial distribution of recharge considering lineament density for Upper Awash and part of the Middle Blue 
Nile basin.

Finally, physically based pattern of spatial distribution of recharge, whereby all important factors affecting not only the amount, but also spatial pattern of recharge have been reasonably accounted for the two river basins separately (Figure 8 and Figure 9).

\section{Conclusions and Recommendations}

\subsection{Conclusions}

WBM, CMB, BFS and HYDRUS 1D techniques have been used to estimate recharge to Upper Awash aquifer system from Upper Awash and southern flank of Middle Blue Nile basins. Multiple "at point" estimates from HYDRUS 1D model recharge simulations were first interpolated by using linear geo-statistical techniques to produce spatial distribution of recharge. In order to consider spatial heterogeneity of most important factors governing recharge between any two point estimates, spatial distribution of recharge produced by ordinary interpolations were superimposed on topography, slope, lineament density and major urban settlements in PMWIN, GIS and SURFER environments. Upper Awash and southern flank of the Middle Blue Nile basins were separately treated to understand the contribution of each basin to the Upper Awash aquifer system.

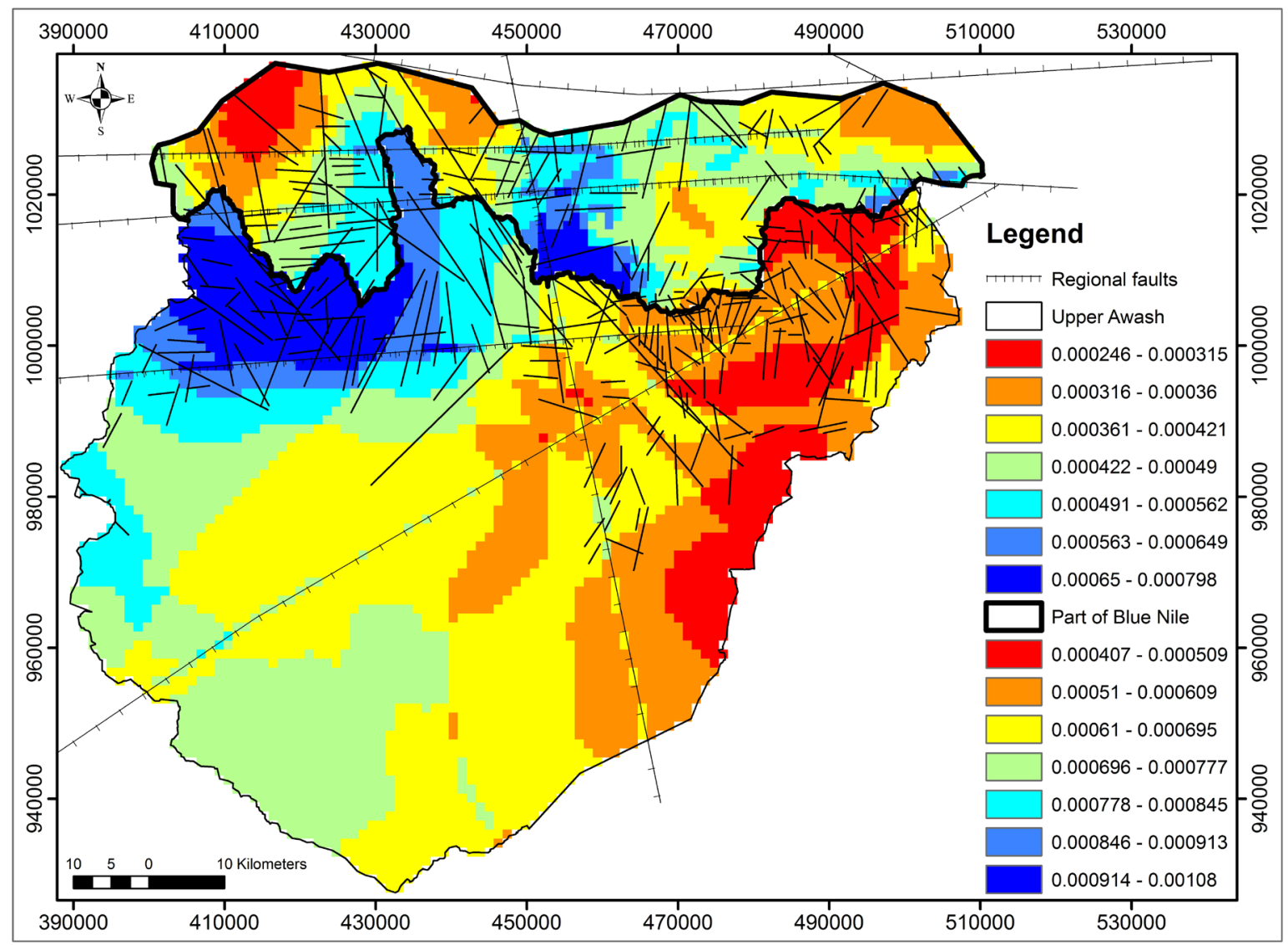

Figure 7. Recharge zones based on HYDRUS 1D model results interpolation superimposed on lineament density in the Upper Awash and part of Blue Nile. 


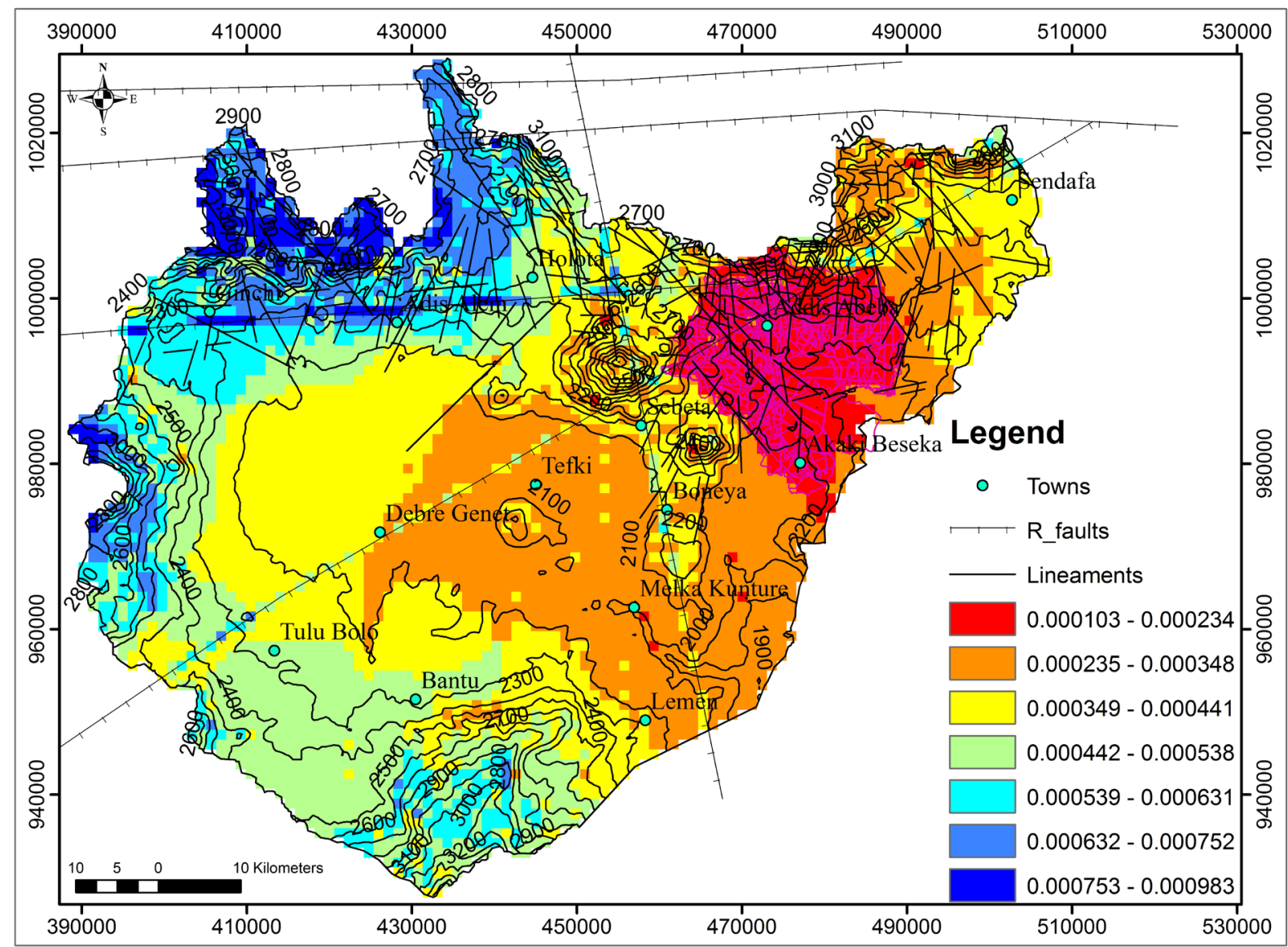

Figure 8. Recharge zones based on HYDRUS 1D model results interpolation superimposed on all factors governing recharge in the Upper Awash.

The recharge estimates using different techniques based on surface water and unsaturated zone data provide estimates of potential recharge ranging from 91 $\mathrm{mm} / \mathrm{yr}$. to $157 \mathrm{~mm} / \mathrm{yr}$. for the Upper Awash and from $86 \mathrm{~mm} / \mathrm{yr}$. to $239 \mathrm{~mm} / \mathrm{yr}$. for the two flanks of Middle Blue Nile basin sub basins (Mugher and Jema). The maximum estimates are from HYDRUS $1 \mathrm{D}$ model simulation, $157 \mathrm{~mm} / \mathrm{yr}$. and $239 \mathrm{~mm} / \mathrm{yr}$. for the Upper Awash and part of the Middle Blue Nile basins respectively. The minimum is from base flow separation. The minimum estimate can be expected since base flow separation techniques yield a proxy which refers to only the minimum amount of recharge.

For the main reason that HYDRUS 1D simulation takes more or less, all the recharge governing factors into account (both surface and sub-surface conditions up to $200 \mathrm{~cm}$ ), the difference between HYDRUS 1D recharge simulated value and base flow recharge approximation possibly explain the range of plausible recharge variation in the study area. The other estimates, WBM $(131 \mathrm{~mm} /$ yr.), CMB (135 mm/yr.) fall between the two.

Significant flux joins the Upper Awash groundwater system from southern flank of Blue Nile basin annually, $365 \mathrm{Mm}^{3}$. Which is almost $37 \%$ of the total annual recharge to the Upper Awash basin, $983 \mathrm{Mm}^{3}$ per annum, making this part of the Blue Bile basin important recharge zone for the Upper Awash. 


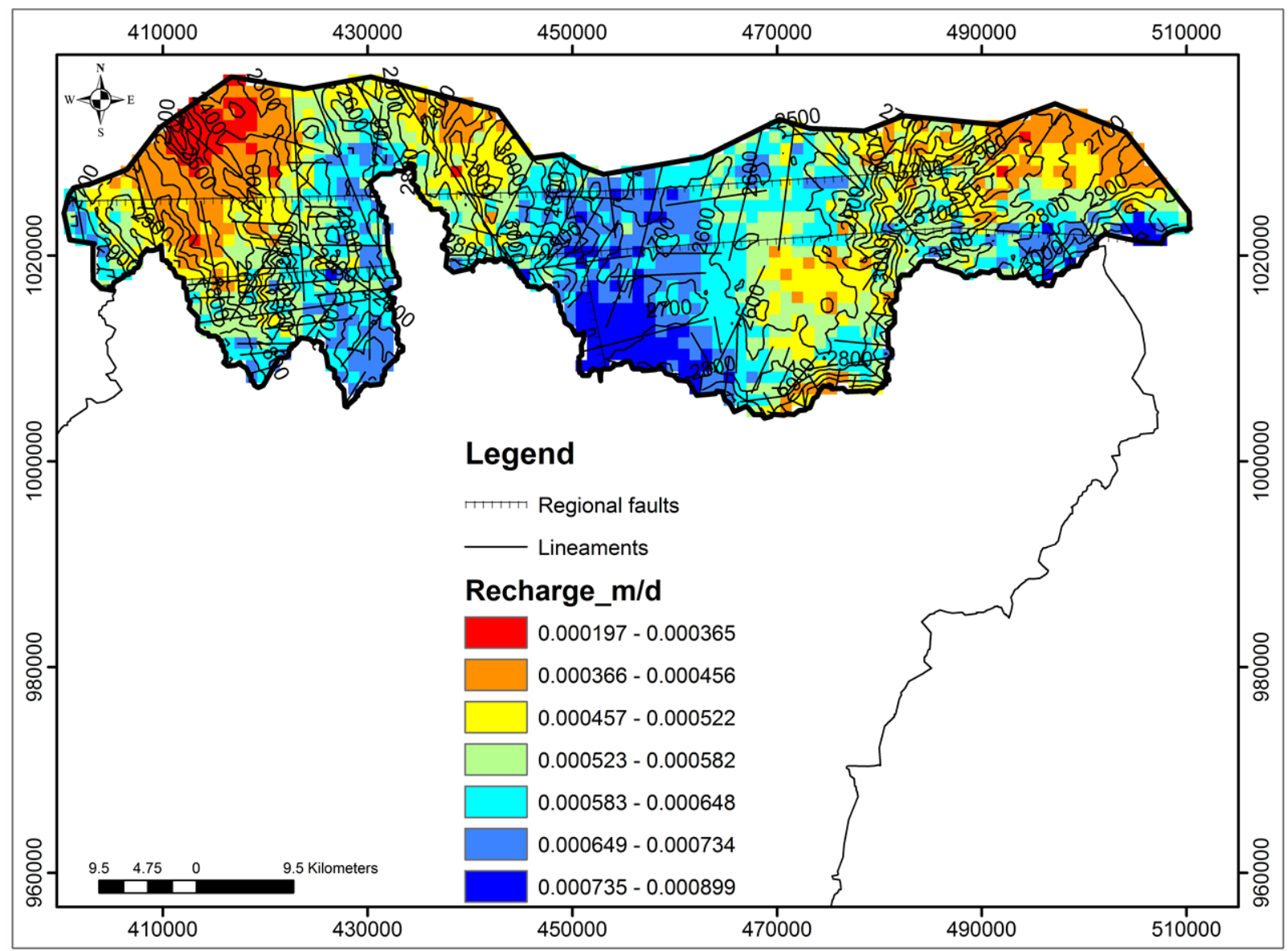

Figure 9. Recharge zones based on HYDRUS 1D model results interpolation superimposed on all factors governing recharge in the partof Blue Nile basin (Mugher and Jema).

This study clearly demonstrates that groundwater recharge estimate is prone to errors based on the method used to estimate in data scares areas. Hence, multiple approaches of recharge estimate enables to minimize the errors and obtain fair estimates and allows understanding how the various catchment factors govern the spatial variability of groundwater recharge.

\subsection{Recommendations}

Together with the amount of recharge, the issues of spatial variability need to be addressed, especially when the research objective goes beyond simple regional estimates of recharge, such as for numerical modeling and contaminant transport simulation.

Most recharge estimation techniques provide multiple "at point" estimates which need to be interpolated to better understand spatial variability of recharge over large areas. However, Simple interpolation of point estimates using linear geo-statistical techniques (Kriging, Spline, IDW etc.) to produce recharge zones possibly overlook heterogeneity between any two point estimates. The interpolated surfaces should, therefore, be superimposed with major recharge governing factors by using other tools including GIS, PMWIN, and SURFER. In doing so, 
physical based pattern of spatial distribution of recharge constrained by most governing factors can be produced.

\section{Acknowledgements}

Addis Ababa Science and Technology University is highly acknowledged for providing a grant for the first author as part of his $\mathrm{PhD}$ research. The Swedish International Development Cooperation Agency (Sida) is also acknowledged for a $\mathrm{PhD}$. research stay grant for the first author through its office at Addis Ababa University in Ethiopia. The authors thank Ministry of Water, Irrigation and Electricity (MoWIE) and National Meteorological Services Agency for provision of river discharge and meteorological data, respectively. Addis Ababa University, School of Earth Sciences is highly acknowledged for provision of field logistics. My special thanks also go to Dr. Habtamu Hailu and Dr. Mesfin Tafesse for their support.

\section{References}

[1] Shaw, E.M. (1994) Hydrology in Practice. 3rd Edition, Chapman \& Hall, London.

[2] Luckey, R.R., Gutentag, E.D., Heimes, F.J. and Weeks, J.B. (1986) Digital Simulation of Ground-Water Flow in the High Plains Aquifer in Parts of Colorado, Kansas, Nebraska, New Mexico, Oklahoma, South Dakota, Texas, and Wyoming. No. 1400-D.

[3] Hendrickx, J.M.H. and Dekker, L.W. (1991) Experimental Evidence of Unstable Wetting Fronts in Homogeneous Non-Layered Soils. Proceedings of the National Symposium on American Society of Agricultural Engineers, Chicago, 16-17 December 1991, 22-31.

[4] Kearns, A.K. (1998) Temporal Variability of Diffuse Groundwater Recharge in New Mexico. Doctoral Dissertation, New Mexico Institute of Mining and Technology, New Mexico.

[5] Nicholson, R.V., Cherry, J.A. and Reardon, E.J. (1983) Migration of Contaminants in Groundwater at a Landfill: A Case Study, 6. Hydrogeochemistry. Journal of Hydrology, 63, 131-176. https://doi.org/10.1016/0022-1694(83)90226-3

[6] Flury, M., Flühler, H., Jury, W.A. and Leuenberger, J. (1994) Susceptibility of Soils to Preferential Flow of Water: A Field Study. Water Resources Research, 30, 19451954. https://doi.org/10.1029/94WR00871

[7] Scanlon, B.R. and Goldsmith, R.S. (1997) Field Study of Spatial Variability in Unsaturated Flow beneath and Adjacent to Playas. Water Resources Research, 33, 2239-2252. https://doi.org/10.1029/97WR01332

[8] Adar, E.M., Neuman, S.P. and Woolhiser, D.A. (1988) Estimation of Spatial Recharge Distribution Using Environmental Isotopes and Hydrochemical Data, I. Mathematical Model and Application to Synthetic Data. Journal of Hydrology, 97, 251-277. https://doi.org/10.1016/0022-1694(88)90119-9

[9] Gieske, A. and De Vries, J.J. (1990) Conceptual and Computational Aspects of the Mixing Cell Method to Determine Groundwater Recharge Components. Journal of Hydrology, 121, 277-292. https://doi.org/10.1016/0022-1694(90)90236-Q

[10] Athavale, R.N., Rangarajan, R. and Muralidharan, D. (1992) Measurement of Natural Recharge in India. Geological Society of India, 39, 235-244.

[11] Edmunds, W.M. and Gaye, C.B. (1994) Estimating the Spatial Variability of 
Groundwater Recharge in the Sahel Using Chloride. Journal of Hydrology, 156, 47-59. https://doi.org/10.1016/0022-1694(94)90070-1

[12] Kennett-Smith, A., Cook, P.G. and Walker, G.R. (1994) Factors Affecting Groundwater Recharge Following Clearing in the South Western Murray Basin. Journal of Hydrology, 154, 85-105. https://doi.org/10.1016/0022-1694(94)90213-5

[13] Bredenkamp, D.B., Botha, L.J., Van Tonder, G.J. and Van Rensburg, H.J. (1995) Manual on Quantitative Estimation of Groundwater Recharge and Aquifer Storativity: Based on Practical Hydro-Logical Methods. Water Research Commission, Pretoria.

[14] Leaney, F.W. and Herczeg, A.L. (1995) Regional Recharge to a Karst Aquifer Estimated from Chemical and Isotopic Composition of Diffuse and Localised Recharge, South Australia. Journal of Hydrology, 164, 363-387. https://doi.org/10.1016/0022-1694(94)02488-W

[15] Sukhija, B.S., Nagabhushanam, P. and Reddy, D.V. (1996) Groundwater Recharge in Semi-Arid Regions of India: An Overview of Results Obtained Using Tracers. Hydrogeology Journal, 4, 50-71. https://doi.org/10.1007/s100400050089

[16] Birkle, P., Rodríguez, V.T. and Partida, E.G. (1998) The Water Balance for the Basin of the Valley of Mexico and Implications for Future Water Consumption. Hydrogeology Journal, 6, 500-517. https://doi.org/10.1007/s100400050171

[17] Selaolo, E.T. (1998) Tracer Studies and Groundwater Recharge Assessment in the Eastern Fringe of the Botswana Kalahari. PhD Thesis, Vrije Universiteit, Amsterdam, 229 p.

[18] Beekman, H.E., Selaolo, E.T. and Vries, J.J. (1999) Groundwater Recharge and Resources Assessment in the Botswana Kalahari: Executive Summary GRES II. Centre for Development Cooperation, Vrije Universiteit, Amsterdam.

[19] Rangarajan, R. and Athavale, R.N. (2000) Annual Replenishable Ground Water Potential of India-An Estimate Based on Injected Tritium Studies. Journal of $\mathrm{Hy}$ drology, 234, 38-53. https://doi.org/10.1016/S0022-1694(00)00239-0

[20] Zhu, C. (2000) Estimate of Recharge from Radiocarbon Dating of Groundwater and Numerical Flow and Transport Modeling. Water Resources Research, 36, 2607-2620. https://doi.org/10.1029/2000WR900172

[21] Lerner, D.N., Issar, A.S. and Simmers, I. (1990) Groundwater Recharge: A Guide to Understanding and Estimating Natural Recharge. Heise, Hannover, Vol. 8, 1-345.

[22] Allison, G.B., Gee, G.W. and Tyler, S.W. (1994) Vadose-Zone Techniques for Estimating Groundwater Recharge in Arid and Semiarid Regions. Soil Science Society of America Journal, 58, 6-14. https://doi.org/10.2136/sssaj1994.03615995005800010002x

[23] Stephens, D.B. (1994) A Perspective on Diffuse Natural Recharge Mechanisms in Areas of Low Precipitation. Soil Science Society of America Journal, 58, 40-48. https://doi.org/10.2136/sssaj1994.03615995005800010006x

[24] Stephens, D.B. (1996) Estimation of Infiltration and Recharge for Environmental Site Assessment. API Publ 4643, Health and Environmental Sciences Department, Albuquerque.

[25] Lerner, D.N., Saether, O.M. and Caritat, P.D. (1997) Groundwater Recharge. In: Saether, O.M. and de Caritat, P., Eds., Geochemical Processes, Weathering and Groundwater Recharge in Catchments, Balkema, Rotterdam, 109-150.

[26] Gee, G.W. and Hillel, D. (1988) Groundwater Recharge in Arid Regions: Review and Critique of Estimation Methods. Hydrological Processes, 2, 255-266.

https://doi.org/10.1002/hyp.3360020306 
[27] Simmers, I. (1997) Recharge of Phreatic Aquifers in (Semi-)Arid Areas. IAH Int. Contrib. Hydrogeol. 19, AA Balkema, Rotterdam, 277 p.

[28] Healy, R.W. and Cook, P.G. (2002) Using Groundwater Levels to Estimate Recharge. Hydrogeology Journal, 10, 91-109.

https://doi.org/10.1007/s10040-001-0178-0

[29] Nimmo, J.R., Healy, R.W. and Stonestrom, D.A. (2005) Aquifer Recharge. Encyclopedia of Hydrological Sciences.

[30] Scanlon, B.R., Healy, R.W. and Cook, P.G. (2002) Choosing Appropriate Techniques for Quantifying Groundwater Recharge. Hydrogeology Journal, 10, 18-39. https://doi.org/10.1007/s10040-001-0176-2

[31] Fetter, C.W. (2001) Applied Hydrogeology. University of Wisconsin-Oshkesh, Oshkesh, $598 \mathrm{p}$.

[32] Craig, H., Lupton, J.E. and Horowiff, R.M. (1977) Isotope Geochemistry and Hydrology of Geothermal Waters in the Ethiopian Rift Valley. Scripps Institute of Oceanography, University of California Report, 160 p.

[33] Darling, W.G. (1996) The Geochemistry of Fluid Processes in the Eastern Branch of the East African Rift System. PhD Thesis, British Geol. Surv., UK, 235 p.

[34] Darling, G., Gizaw, B. and Arusei, M. (1996) Lake-Groundwater Relationships and Fluid-Rock Interaction in the East African Rift Valley: Isotopic Evidence. Journal of African Earth Sciences, 22, 423-430. https://doi.org/10.1016/0899-5362(96)00026-7

[35] Gizaw, B. (2002) Hydrochemical and Environmental Investigation of the Addis Ababa Region, Ethiopia. Unpublished PhD Thesis, Ludwig Macmillan University of Munich, Munich.

[36] Chernet, T., Travi, Y. and Valles, V. (2001) Mechanism of Degradation of the Quality of Natural Water in the Lakes Region of the Ethiopian Rift Valley. Water Research, 35, 2819-2832. https://doi.org/10.1016/S0043-1354(01)00002-1

[37] Reimann, C., Bjorvatn, K., Frengstad, B., Melaku, Z., Tekle-Haimanot, R. and Siewers, U. (2003) Drinking Water Quality in the Ethiopian Section of the East African Rift Valley I-Data and Health Aspects. Science of the Total Environment, 311 65-80. https://doi.org/10.1016/S0048-9697(03)00137-2

[38] Demlie, M., Wohnlich, S. and Ayenew, T. (2008) Major Ion Hydrochemistry and Environmental Isotope Signatures as a Tool in Assessing Groundwater Occurrence and Its Dynamics in a Fractured Volcanic Aquifer System Located within a Heavily Urbanized Catchment, Central Ethiopia. Journal of Hydrology, 353, 175-188. https://doi.org/10.1016/j.jhydrol.2008.02.009

[39] Bretzler, A., Osenbrück, K., Gloaguen, R., Ruprecht, J.S., Kebede, S. and Stadler, S. (2011) Groundwater Origin and Flow Dynamics in Active Rift Systems-A Multi-Isotope Approach in the Main Ethiopian Rift. Journal of Hydrology, 402, 274-289. https://doi.org/10.1016/j.jhydrol.2011.03.022

[40] Kebede, S., Travi, Y., Alemayehu, T. and Ayenew, T. (2005) Groundwater Recharge, Circulation and Geochemical Evolution in the Source Region of the Blue Nile River, Ethiopia. Applied Geochemistry, 20, 1658-1676.

https://doi.org/10.1016/j.apgeochem.2005.04.016

[41] WWDSE (2008) Adaa-Becho Groundwater Resource Evaluation for Irrigation. Unpublished Report, Addis Ababa, Ethiopia.

[42] Yitbarek, A. (2009) Hydrogeological and Hydrochemical Framework of Complex Volcanic System in the Upper Awash River Basin, Central Ethiopia. Unpublished PhD Thesis, University of Poitiers, Poitiers. 
[43] Yitbarek, A., Razack, M., Ayenew, T., Zemedagegnehu, E. and Azagegn, T. (2012) Hydrogeological and Hydrochemical Framework of Upper Awash River Basin, Ethiopia: With Special Emphasis on Inter-Basins Groundwater Transfer between Blue Nile and Awash Rivers. Journal of African Earth Sciences, 65, 46-60. https://doi.org/10.1016/j.jafrearsci.2012.01.002

[44] Furi, W. (2011) Hydrogeological System Analysis of the Middle Awash Basin, Ethiopia. Unpublished PhD Thesis, University of Poitiers, Poitiers.

[45] Azagegn, T., Asrat, A., Ayenew, T. and Kebede, S. (2014) Litho-Structural Control on Interbasin Groundwater Transfer in Central Ethiopia. Journal of African Earth Sciences, 101, 383-395. https://doi.org/10.1016/j.jafrearsci.2014.10.008

[46] Azagegn, T. (2015) Groundwater Dynamics between the Upper Awash and the Left Bank Catchments of the Blue Nile Aquifer Systems.

[47] Eriksson, E. and Khunakasem, V. (1969) Chloride Concentration in Groundwater, Recharge Rate and Rate of Deposition of Chloride in the Israel Coastal Plain. Journal of Hydrology, 7, 178-197. https://doi.org/10.1016/0022-1694(69)90055-9

[48] Simunek, J., Sejna, M. and van Genuchten, M.T. (1996) Hydrus-2D: Simulating Water Flow and Solute Transport in Two-Dimensional Variably Saturated Media. International Groundwater Modeling Center, Colorado School of Mines, Golden.

[49] Van Genuchten, M.T. (1980) A Closed Form Equation for Predicting the Hydraulic Conductivity of Unsaturated Soils. Soil Science Society of America Journal, 44, 892-898. https://doi.org/10.2136/sssaj1980.03615995004400050002x

[50] Van Genuchten, M.T. (1987) A Numerical Model for Water and Solute Movement in and below the Root Zone. United States Department of Agriculture Agricultural Research Service US Salinity Laboratory.

[51] Van Genuchten, M.T. (2013) The Hydrus-1D Software Package for Simulating the One-Dimensional Movement of Water, Heat, and Multiple Solutes in Variably-Saturated Media.

[52] Gemechu, D. (1977) Aspects of Climate and Water Budget in Ethiopia. Addis Ababa University Press, Addis Ababa, 71 p.

[53] FAO (1984) Soil and Land Use/Land Cover Map of Africa. Food and Agriculture Organization of the United Nations.

[54] Rutledge, A.T. (2000) Considerations for Use of the RORA Program to Estimate Ground-Water Recharge from Stream Flow Records. US Geological Survey Open-File Report 00-156, 44 p.

[55] Rushton, K.R. (1988) Numerical and Conceptual Models for Recharge Estimation in Arid and Semi-Arid Zones. In: Simmers, I., Ed., Estimation of Natural Groundwater Recharge, NATO ASI Series C 222, Reidel, Dordrecht, 223-238. https://doi.org/10.1007/978-94-015-7780-9 14

[56] Hem, J.D. (1985) Research and Interpretation of the Chemical Characteristics of Natural Water. 3rd Edition, US Geological Survey Water Supply Paper 2254, 1-263.

[57] Somaratne, N. and Smettem, K.R.J. (2014) Theory of the Generalized Chloride Mass Balance Method for Recharge Estimation in Groundwater Basins Characterized by Point and Diffuse Recharge. Hydrology and Earth System Sciences Discussions, 11, 307-332. https://doi.org/10.5194/hessd-11-307-2014

[58] Daniel, C.C. (1996) Ground-Water Recharge to the Regolith-Fractured Crystalline Rock Aquifer System, Orange County, North Carolina, No. 96-4220.

[59] Brooks, R.H. and Corey, A.T. (1964) Hydraulic Properties of Porous Media and Their Relation to Drainage Design. Transactions of the ASAE, 7, 26-28. https://doi.org/10.13031/2013.40684 
[60] Feddes, R.A., Kowalik, P.J. and Zaradny, H. (1978) Simulation of Field Water Use and Crop Yield. Centre for Agricultural Publishing and Documentation.

[61] Celia, M.A., Russell, T.F., Herrera, I. and Ewing, R.E. (1990) An Eulerian-Lagrangian Localized Adjoint Method for the Advection-Diffusion Equation. Advances in Water Resources, 13, 187-206. https://doi.org/10.1016/0309-1708(90)90041-2

[62] Hijmans, R.J., Cameron, S.E., Parra, J.L., Jones, P.G. and Jarvis, A. (2005) Very High Resolution Interpolated Climate Surfaces for Global Land Areas. International Journal of Climatology, 25, 1965-1978. https://doi.org/10.1002/joc.1276

[63] Szilagyi, J., Harvey, F.E. and Ayers, J.F. (2003) Regional Estimation of Base Recharge to Ground Water Using Water Balance and a Base-Flow Index. Ground Water, 41, 504-513. https://doi.org/10.1111/j.1745-6584.2003.tb02384.x

[64] Holtschlag, D.J. (1997) A Generalized Estimate of Ground-Water-Recharge Rates in the Lower Peninsula of Michigan. US Geological Survey Water-Supply Paper 2437, $1-37$.

[65] Foster, S.S.D., Morris, B.L. and Lawrence, A.R. (1994) Effects of Urbanization on Groundwater Recharge. Proceedings of the ICE International Conference on Groundwater Problems in Urban Areas, London, June 1994, 43-63.

[66] Chilton, P.J. (1997) Groundwater in the Urban Environment. AA Bakema, Rotterdam, Vol. 1, 685.

[67] Dennis, W.R., William J.G. and Gordon J.F. (2009) Comparison of Recharge Estimates at a Small Watershed in East-Central Pennsylvania, USA. Hydrogeology Journal, 17, 287-298. https://doi.org/10.1007/s10040-008-0406-y

[68] Girmay, H. and Assefa, G. (1989) The Addis Ababa-Nazareth Volcanics: A Miocene-Pleistocene Volcanic Succession in the Ethiopian Rift. SINET: Ethiopian Journal of Science, 12, 1-24.

\section{Submit or recommend next manuscript to SCIRP and we will provide best service for you:}

Accepting pre-submission inquiries through Email, Facebook, LinkedIn, Twitter, etc. A wide selection of journals (inclusive of 9 subjects, more than 200 journals)

Providing 24-hour high-quality service

User-friendly online submission system

Fair and swift peer-review system

Efficient typesetting and proofreading procedure

Display of the result of downloads and visits, as well as the number of cited articles

Maximum dissemination of your research work

Submit your manuscript at: http://papersubmission.scirp.org/

Or contact gep@scirp.org 